使用経験が少なしために起る故障や同じ機種を使用して いる施設ては，同しょうな故障も多く相互の連絡を取り 合うととによっててれル対処する必要がある。

\section{シンポジウム「CT の技術的諸問題」}

\section{CT の概要}

$$
\text { 東芝メディカル株式会社 CT 営業部 }
$$
永洞 昭義

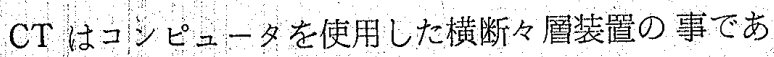
り，1971年に英国のハンスフィールドにより完成された。 促来のX線写真に比へて軟部組織を良〈描出し，その彰 断佂值は高く評価されている。

[ 1$]$ 画像め再構成

$\mathrm{CT}$ では撮影する横断面を細しX線ビームで走查し， その断面の投影像を電気信号しして取り出し，多方向か らの投影像を用いてコンピュータで断面像を再構成す る.

\section{〔2】 CT Ф世代}

投影像を得る為のスキャン方式により分類する事がで き,をれぞれ長所短所がある。

第一世代 (ペンンルビーム)、第二世代(ファンビーム $\mathrm{T} / \mathrm{R})$. 第三世伐 (つナンビーム, $360^{\circ}$ 回転)，第四伳代 (マルチソース・マルチディテクタ).

\section{[3] CT-Number と標準偏差}

被検体各部の吸收係数は装置に固有の数值(CT-Number) で表現される. 又, その精度は水ファントムを使用

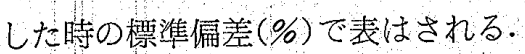

\section{〔4】 CT の画像汇影響する三つの要素}

CT 像恃，X線量，マトリックスサイズ (空間解像度), 精度 (密度解像度) の相反する三つの条件に影響され る. 徒って彰断価值の高い画像を得る為には，使用目的 儿応して異る条件を選択できる事が望まれる。

\section{CT の普及状況と問題点}

\section{大分県立病院 甲斐敏久}

X線界の革命とも言われる装置が，出現して以来，そ の医療界への普及は予想されたものとは言え，警くへき あのである，乙れに対し私達放射線技師は，それをよく 見きかめて使用する事が大切である。CT の普及状沉に は，さまざまな問題点がある，わが国に扎てい，国 公立病院よりも私立病院での普及が多いのである。この 装置に関してもいままでの放射線機器と同じように, 放 射線技師さえいなく，被曝管理さえも行なわれていない ような場所で使用されはしないかとおおわれるのであ る. またスタッフの問題, 空口の問題にしても決してそ
の検查決定において，ただ放射線を使用するというだけ の理由から，まったくの素人である放射線医が独占する ような事はさりるべきである.必ず神経放射線医，もし くは脳外科医や神経内科医等の専門医と放射線技師の子 とに行なわれるべきである。また将来に执いては，もし 各社装置の規格作成ができれば計算機だけを共同使用す る事もコストの面から有利である。CT は我々が思って いたよりあ，かなり被曝線量が多いように怙もわれる。 高感度検出器の開発や，X線のパルス状発生等は早急に 行なわれるべきであ万う.

\section{CT-1000における基礎的実験}

長崎大学医学部附属病院放射線部 O松尾英典・福田正守·安岡 新 春田隆昌・周藤匠司・平形次男 山口昌一.今泉美治

CT-1000 の技術的諸間題として 基礎的実験をおうな

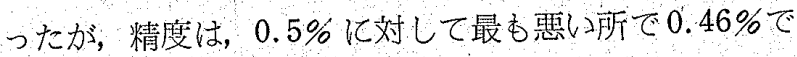
規定值以下であった。 又高い精度を有している事が確認 出来た。 しかし定量, 定性判断する場合物質の描出サイ ズ並びに吸收值の変化する要因がかなり多く，不安定で 今後検討されなければならない。スライス厚は，何れる 公称值どうりなく，次のスライス面との間に空白領域を 生じ，両スライス間はは，重複領域がある事がブラウン 管の残光特性を利用して推測出来る，分解能は，周りの 物質に対して吸収值が高いものは $1 \mathrm{~mm}$ 迄現出出来るが， 低くなるに從い現出能力が変わる。乙れは，病巣の種類 により描出能力が変わり，発見出来る大きさが変化する 事を示している. 他にも変化する要因として，管電圧， 管電流，PMC 有無，コリメーターが挙げられる。アー ティファクトでは，PMCの効用を試したが，縦のスト リークは，静止，運動像共に顕著に消失した. 被晎線量 では，X-ray がコリメートされているにあかかわらずか なりの散乱附加があり, 容積線量が多い. 又深部線量, 水昌体被曝が他頭部諸検查に比しかなり多い為，眼への プロテクト， ポシショニング，幾何学的諸条件の考慮等 による患者被曝の軽減を計らねばならない，又1スキャ ンの $2 \sim 3$ 倍に比較して，2 2 スキャン，3スキャンでは， 各々 $20 \sim 30 \% ， 40 \sim 50 \%$ の線畫增加が認められる.

\section{CT の臨床面における問題点}

鹿児島大学医学部附属病院放射線部 中村 純雄

現在, CT 検查の診断価值は高く評価され, 脳外科領 域では久くととの出来ない検查法とまで言われており， 頭部单純X線写真，脳血管造影など併用するととで㭘査 